\title{
The Effect of Mulaka Beejadi Lepa and Pruthu Nimba Panchaka Churna in the Management of Vicharchika W.S.R. to Eczema
}

\author{
Research Article
}

\section{Divya $\mathbf{V}^{1^{*}}$, Ragamala K $\mathrm{C}^{2}$}

1. PG Scholar, 2. Assistant Professor, Department of Kaumarabhrithya . S.V. Ayurvedic College, Tirupati, A.P, India.

\begin{abstract}
According to Ayurveda, Vicharchika is a major problem in skin diseases. All Kusthas are having Tridoshaja origin. The disease Vicharchika to a greater extent resembles eczema/dermatitis. Despite of great advance in dermatology and the advent of powerful antibiotics, antifungal as well as steroids, Eczema continues to defy the best effect of dermatologists. Hence it is the need of the hour to find out safe and effective medicine for Vicharchika and here comes the role of Ayurveda. The involvement of Vata results in dry, blackish lesion of eczema, itching in those affected areas is due to Kapha and Pitta is responsible for Srava. In classical texts, Ayurveda Acharyas emphasizes shodhana and shamana therapy as the line of treatment at various contexts. So, the study aimed to evaluate efficacy of Mulaka beejadi lepa and Pruthu nimba panchaka churna in vicharchika, 30 children aged 3-16years who were fulfilling the inclusion criteria and diagnostic criteria were selected from Kaumarabhritya OPD and IPD of S.V.Ayurvedic College \& Hospital, Tirupati. Patients were given Mulaka beejadi lepa as external application and vati prepared with Pruthu nimba panchaka churna 250mg BID in 310 years age group and 500mg BID in 11-16yrs age group children for 30days and called for follow up after 15days to note any recurrence.The cases were recorded as per the case Pro forma and observations were recorded. Symptoms were scored and statistically analysed for any change before and after treatment. Mulaka Beejadi lepa as external application and Pruthu Nimba panchaka churna internally are very effective in the management of vicharchika.
\end{abstract}

\section{Keywords: Kustha, Vicharchika, Eczema Mulaka beejadi lepa, Pruthu nimba panchaka churna.}

\section{Introduction}

Ayurvedic physicians are providing good health to human race by treating their diseases with the help of Ayurvedic principles since thousands of years ago. Dermatological problems are seen by pediatricians every day and comprise of around one quarter of a busy outpatient clinic (1). In Ayurveda all types of skin diseases have been discussed under the broad heading of kushta which is further divided as Maha kustha and Kshudra kustha (2). Acharyas considered vicharchika as kshudra kustha(3) . Different acharyas have defined vicharchika in different ways.

In shabdha kalpa druma the disease which coats or covers the skin in particular manner and causes cracking of skin of hands and feet mainly

As per Acharya Charaka the skin disease where eruptions over the skin appear with dark pigmentation, itching with profuse discharge from lesion are seen is vicharchika(4).

According to Sushruta, Disease where severe itching, severe pain, and dryness is seen is Vicharchika (5).

\section{*Corresponding Author:}

\section{Divya V}

PG Scholar,

Department of Kaumarabhrithya,

SV Ayurvedic College,

Tirupati, Andhra Pradesh. India

Email id: divitheone555@gmail.com
Acharya Kashyapa says Black, red ulcers with pain, discharges and suppuration is Vicharchika(6).

Vicharchika, according to Ayurveda is Rakta Pradosaja Vikara having involvement of tri dosha with dominance of Kapha, with symptoms of kandu, srava, pitika, vivarnata, rukshata (7). It can be co-related with eczema, according to allopathic view. Eczema is noncontagious inflammation of the skin characterised by erythema, scaling, edema, vesiculation and oozing. It also effects psychological status and disturb social life due to its appearance (8). It causes disturbed sleep and poor growth (9).Eczema is most common relapsing skin disease seen in infancy and childhood (10). It is slightly more common in boys than in girls (11). Now a days, modern science has advanced so much particularly in dermatology as topic is concerned and also with availability of powerful antibiotics, antifungal, antihistaminic, steroids etc., but better management is not been searched out till today.

Ayurvedic system of medicine is generally considered as the best for most of the skin diseases. Holistic approach of Ayurveda is particularly useful in treating skin diseases, which is often a manifestation of systemic illnesses. In Ayurveda, Shodhana, Shamana and Nidana parivarjana are the principle treatment for any disease. Shaman chikitsa is more preferable than Shodhana chikitsa in paediatric age group, because children have mridu and sukumar body constitution. The selected drug compounds, i.e. MULAKA BEEJADI LEPA and PRUTHU NIMBA PANCHAKA CHURNA are well indicated for Kushta and both act as Shaman dravyas in Kustha especially in vicharchika. 
Aims and Objectives

To study the efficacy of Mulaka Beejadi Lepa and Pruthu Nimba Panchaka churna in Vicharchika.

To study in detail about the etiopathogenesis and prevalence of Vicharchika in the light of description available for Eczema in modern science.

\section{Materials and Methods}

The materials and methods used and the modifications made was based on easy availability of the drugs, feasibility of the methods, available literature, traditional experiences and expert opinions.

\section{Mulaka Beejadi Lepa (12)}

$\begin{array}{ll}\text { Drug } & \text { Quantity } \\ \text { Mulaka beeja } & \text { 1part } \\ \text { Sarshapa } & \text { 1part } \\ \text { Laksha } & \text { 1part } \\ \text { Haridra } & \text { 1part } \\ \text { Chakramarda beeja } & 1 \text { part } \\ \text { Srivestaka } & 1 \text { part } \\ \text { Sunti } & 1 \text { part } \\ \text { Pippali } & 1 \text { part } \\ \text { Maricha } & 1 \text { part } \\ \text { Vidanga } & 1 \text { part } \\ \text { Kusta } & 1 \text { part }\end{array}$

\section{Method}

Preparation of Mulaka beejadi Lepa:

Above said Lepa ingredients were made into very fine powder after drying properly. Madhucchista and Narikela taila are taken as base elements for lepa. They are heated together and fine powder of above drugs are added to it to get lepa consistency. They are cooled down till it gets solidified. The lepa is applied on lesions.

$\begin{array}{ll}\text { Pruthu Nimba Panchaka Churnam (13) } \\ \text { Drug } & \text { Quantity } \\ \text { Nimba tvak } & \text { 1part } \\ \text { Nimba sara } & \text { 1part } \\ \text { Nimba beeja } & \text { 1part } \\ \text { Nimba pushpa } & \text { 1part } \\ \text { Nimba patra } & \text { 1part } \\ \text { Sunti } & \text { 1part } \\ \text { Pippali } & \text { 1part } \\ \text { Maricha } & \text { 1part } \\ \text { Haridra } & \text { 1part } \\ \text { Amalaki } & \text { 1part } \\ \text { Hareetaki } & \text { 1part } \\ \text { Vibheetaki } & \text { 1part } \\ \text { Madhu } & \text { Enough quantity to roll in to pills } \\ \text { Ghrita } & \text { Enough quantity to roll in to pills }\end{array}$

\section{Method:}

Preparation of Pruthu nimba panchak a churna vati

The above ingredients are made into fine powder. Madhu and ghrita were added to it and made it into a dough form, which does not stick to the fingers. This dough is rolled into pills of $250 \mathrm{mg}$ each.

\section{Source of data}

About 30 children aged between 3-16years were randomly selected for the study from OPD and IPD of Department of Kaumarabhrithya, S.V. Ayurvedic Hospital, Tirupati.

\section{Selection of Patients}

Total 30 patients were selected and registered from O.P.D. and IPD of department of Kaumarabhrityam, S. V. Ayurvedic Hospital, based on the inclusion Criteria and clinical features mentioned.

\section{Method of study}

30 children aged between 3-16years were randomly selected and were treated with Mulaka beejadi lepa as external application and vati prepared with Pruthu nimba panchaka churna 250mg BID in 310years age group and 500mg BID in 11-16yrs age group children for 30days and called for follow up after 15 days.

\section{Counselling}

Counselling for both Parents and Guardian was given explaining the nature of the disease and its prognosis.

\section{Diagnostic criteria}

For the diagnosis and assessment of vicharchika in children, Scoring criteria for subjective parameters, SCORAD Score were adopted.

\section{Inclusive Criteria}

- Patients of age group 3-16 years.

- Patients with signs and symptoms of Vicharchika.

- Signs and symptoms of Eczema.

\section{Exclusive Criteria}

- Age group > 16 years.

- Children with any other chronic skin diseases like psoriasis.

- Children with other debilitating diseases like SLE,TB

- Children under any systemic medication.

- Other types of Kustha that are asadhya.

Drug and posology:

- Patients were given Mulaka beejadi lepa as external application and vati prepared with Pruthu nimba panchaka churna $250 \mathrm{mg}$ BID in 3-10years age group and $500 \mathrm{mg}$ BID in 11-16yrs age group children for 30days

Duration:

- The period of study will be for one month.

\section{Follow up of the Study}

- All the cases are followed up with an interval of 15days between each sitting for the progress or changes during treatment.

- Total treatment schedule was for 30 days (active trial phase). The patients were called on $45^{\text {th }}$ day to note any reoccurrence. 


\section{Assessment criteria}

\section{Subjective Criteria}

Kandu, pidika, srava, rukshata, vaivarnyata, ruja, and daha are the signs and symptoms of vicharchika

\section{Scoring criteria for subjective parameters:}

1. Kandu (Itching)

0 - No itching

1 - Mild itching not disturbing normal activity

2 - Occasional itching disturbs normal activity

3 - Itching present continuously and even disturbing sleep

2. Daha (Burning)

0 - No burning sensation

1 - Mild type of burning not disturbing normal activity

2 - Occasionally burning disturbing normal activity

3 - Burning present continuously and even disturbing sleep

\section{Srava (Discharge)}

0 - No discharge

1 - Moisture on the skin lesion

2- Weeping from the skin lesion

3- Weeping from the skin lesion followed by crusting

4. Rukshata

0 - No dryness

1 - Dryness with rough skin (Ruksha)

2 - Dryness with scaling (Khara)

3 - Dryness with cracking (Parusha)

5. Pidika

0 - No eruption in the lesion

1 - Scanty eruptions in few lesions

2- Scanty eruptions in at least half of the lesion

3- All the lesions full of eruption

6. Vaivarnyata

0 - Nearly normal skin color

1 - Brownish red discoloration

2 - Blackish red discoloration

3 - Blackish discoloration

\section{Objective Criteria}

- Absolute Eosinophil count.

- SCORAD International scoring system

\section{Criteria for overall assessment}

Total effect of therapy on 30 patients of vicharchika was calculated by taking the mean of $\%$ of relief.

- Cured - Patients showing 100\% improvement in signs and symptoms have been considered as cured.

- Complete Remission - Patients showing more than $61-99 \%$ average improvement in the Signs and Symptoms have been considered as complete remission.

- Marked improved - the patients showing improvement in between 41-60\% in Signs and Symptoms has been considered as Marked improved.

- Partially improved - the patients showing improvement in between $25-40 \%$ in Signs and Symptoms has been considered as Mild improved.

- Unchanged - no change or less than $25 \%$ improvements in Signs and Symptoms have been considered as unchanged.

\section{Observation:}

Among 30 patients completed the treatment and follow up. Maximum number of children's belongs to 11-15 years of age group $(56.66 \%)$, Male child $(66.66 \%)$, resident of Jangala desha $(80 \%)$, Hindu religion (86.66\%), Mandagni (46.67\%), mixed diet (90\%), Vata Pradhana Prakruti (43.33\%), Madhyama Samhanana (66.67\%), poor socioeconomic class (50\%) and maximum number of patients consumed more $\mathrm{Katu}$, Lavana and Amla Ras i.e. $73.33 \%, 70 \%, 66.67 \%$ respectively, family $\mathrm{H} / \mathrm{o}$ allergy $(46.67 \%)$ and eczema $(43.33 \%)$. The symptoms of Vicharchika like Kandu (100\%), Vaivarnya (100\%), Pidika (56.66\%), Rukshata (53.33\%), Srava (46.66\%), Daha (40\%), Ruja (16.67\%) and Rajyo (16.66\%).

\section{Results}

Effect of therapy on subjective and objective parameters

Extremely significant results $(P<0.001)$ were found in parameters like Kandu, Vaivarnya, Rookshata, Pidika, Srava and decrease in SCORAD scoring, A.E.C. (absolute Eosinophil count). Significant $(P<0.01)$ results were noticed in Ruja and very significant result for Daha.

Table No:1 Showing Effect of therapy on subjective and objective parameters

\begin{tabular}{|c|c|c|c|c|c|c|c|c|}
\hline Parameters & \multirow{2}{*}{$\mathbf{n}$} & \multicolumn{2}{|c|}{ Mean } & \multirow{2}{*}{ \%of relief } & \multicolumn{2}{|c|}{ SD } & \multirow{2}{*}{ t } & \multirow{2}{*}{ P } \\
\cline { 3 - 3 } & & $\mathbf{B T}$ & $\mathbf{A T}$ & & $\mathbf{B T}$ & $\mathbf{A T}$ & & \\
\hline Itching (Kandu) & 30 & 2.00 & 0.43 & $80 \%$ & 0.74 & 0.50 & 12.6393 & $<0.001$ \\
\hline Eruption (Pidika) & 30 & 1.13 & 0.40 & $61.76 \%$ & 1.11 & 0.56 & 5.4302 & $<0.001$ \\
\hline Discharge (Srava) & 30 & 1.23 & 0.43 & $64.86 \%$ & 1.33 & 0.63 & 4.9418 & $<0.001$ \\
\hline Dryness (Rukshata) & 30 & 0.97 & 0.37 & $62.06 \%$ & 1.10 & 0.56 & 4.8711 & $<0.001$ \\
\hline Discolouration (Vivarnata) & 30 & 1.80 & 0.60 & $66.66 \%$ & 0.71 & 0.62 & 9.8932 & $<0.001$ \\
\hline Pain (Ruja) & 30 & 0.30 & 0.07 & $77.77 \%$ & 0.75 & 0.25 & 2.2488 & 0.323 \\
\hline Burning sensation (Daha) & 30 & 0.80 & 0.30 & $62.5 \%$ & 1.03 & 0.60 & 3.5254 & 0.014 \\
\hline AEC & 30 & 726.23 & 451.30 & $37.28 \%$ & 132.70 & 113.08 & 11.7857 & $<0.001$ \\
\hline SCORAD & 30 & 36.463 & 13.737 & $62.33 \%$ & 8.441 & 8.828 & 15.5347 & $<0.001$ \\
\hline
\end{tabular}


Table No 2 Showing Overall assessment of therapy

\begin{tabular}{|l|c|c|}
\hline Overall assessment & No.of patients & Percentage \\
\hline Cured & 4 & $13.33 \%$ \\
\hline Complete remission & 15 & $50 \%$ \\
\hline Marked relief & 11 & $36.66 \%$ \\
\hline Partial relief & 0 & $0 \%$ \\
\hline Not cured & 0 & $0 \%$ \\
\hline
\end{tabular}

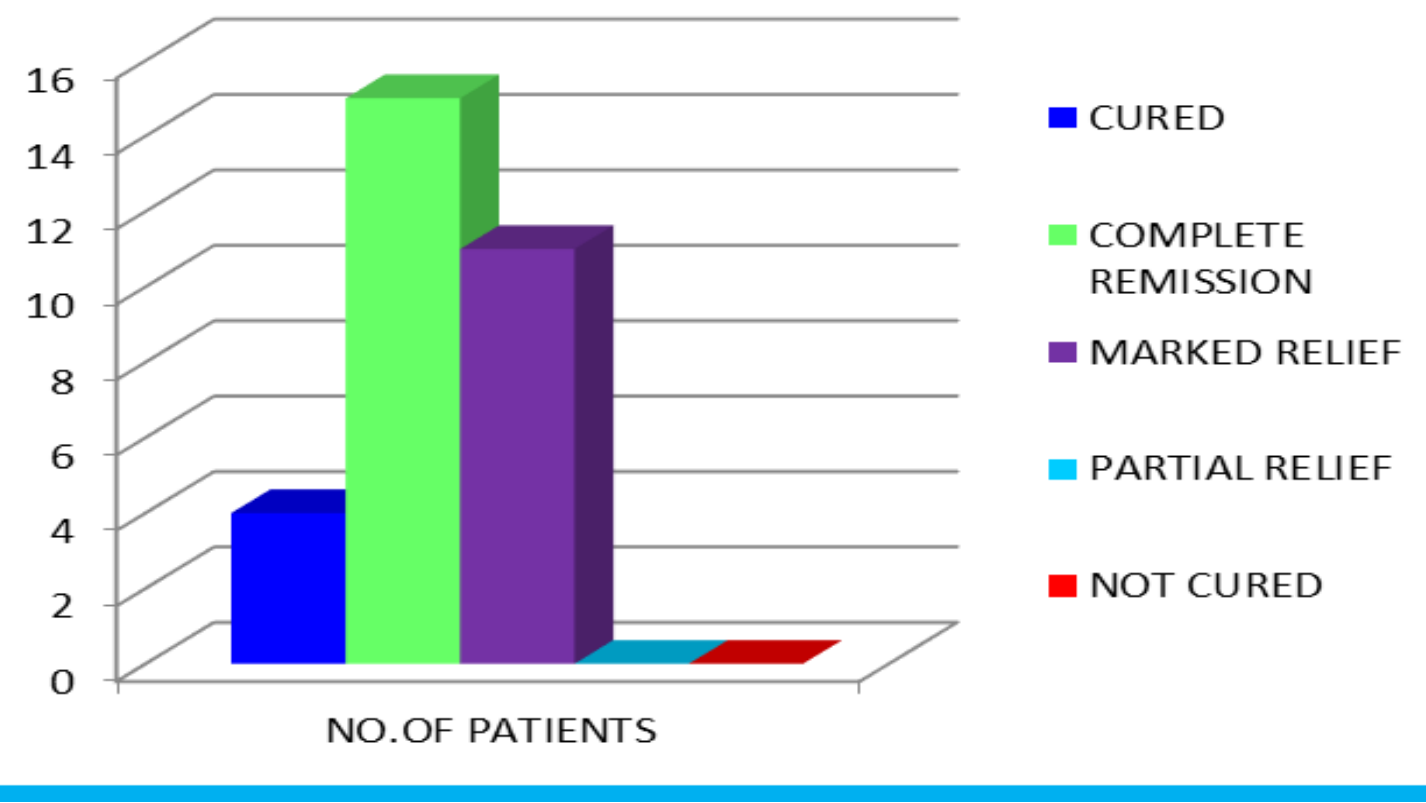

In a sample of 30 patients, maximum patients were having complete remission i.e., $50 \%, 36.66 \%$ of patients show marked relief, and $13.33 \%$ patients show complete cure.

\section{Discussion}

Vicharchika is one of the chronic skin diseases. Atopic dermatitis or Eczema is the most common relapsing skin disease seen in infancy and childhood. It affects $10-30 \%$ of children worldwide and frequently occurs in families with asthma, allergic rhinitis, and food allergy (14).

Vicharchika has been mentioned in almost all Ayurvedic texts, either in form of Kshudra Kustha or Sadhya Kustha.

Various Acharyas mentioned Vicharchika with different Doshic involvement of vision of their symptomatological complex. Charka says that Vicharchika has a Kapha dominancy, because there is an excess Kandu (itching), vivarnata (discoloration),Pidika (boil), srava (profuse oozing), which also indicates its initial or acute stages.

Characteristics like Raji (marked lining) and Arti (pain) and Ruksha (dryness) etc., which indicate chronic or later stage. Thus, this separation may also suggest different stage of disease Vicharchika.

In initial stage of Vicharchika when pruritus may be severe, ultimately skin intactness may rupture and water discharge may produce which is also mentioned by Vagbhata that Vicharchika has a characteristic like Lasikadhya while Indu explained it with Jalapraya i.e. watery discharge.
The symptomatology of Vicharchika is similar with Eczema i.e., Sakandu (excessive itching), Pidika (papule/pustule/vesicle), Shyava (discoloration/hyper pigmentation), Bahusraval (profuse oozing) and later Raji (marked linings/lichenification/Cris-cross marking), Ruja (pain), Saruksha (excessive dryness).

The etiopathogenesis is also similar to Eczema i.e. Viruddha, Mithya Ahara and vihara and other nidana may act as metabolic toxins or other irritant and produce sensitization of skin.

After above discussion it can be said that Vicharchika is a clinical entity in which the lesion has been Shyava colored of Pidika with excessive itching and oozing, which may develop anywhere in the body, either wet or dry.

Eczema can be considered in same category because first manifestation of eczema is erythema or reddening of skin, edema, vesiculation, oozing, crusting and later lichenification. Due to the intra and extra environmental changes in body and its reactions against them, may produce extreme stage of Vicharchika.

Main place of etiopathogenesis, which has been in Tvak (Adhisthana), Rakta (blood and lymph), Mamsa (deep cutaneous tissue) and Lasika (sweat gland apparatus). 
Probable Mode of Action

\section{Mulaka Beejadi Lepa}

Vicharchika is a kapha predominant disease. Most of the drugs used in the formulation have katu, tikta rasa, laghu, ruksha teekshna guna, ushna veerya and katu vipaka. These properties of drugs helps in alleviating kapha and pitta dosha.

All the drugs in combination having Kushtaghana, Kandughana, Krimighna, Rasayana and also Varnya, lekhana, daha prashamana properties.

Mulaka Beeja reduces the dryness of the skin, cracks and moisturizes the skin from inside.thus reducing the rukshatva guna in vicharchika(15). Presence of sulphur compound in Mulaka Beeja possess Kitari,Pamari,Kusthaghna properties(16).

Sarshapa shows Vedana sthapana property. Antiulcerogenic and wound healing property of Laksha helps in healing of the lesions(17).

Lekhaniya guna of haridra is useful for reduction of thickness of skin and vaivarnyata in the disease.

The srava in vicharchika is controlled by Sleshma puti hara,Vrana shodaka and Dusta Vrana hara properties of Srivestaka(18). Anti oxidant, Kandughna, Krimighna, Dadru hara and Lekhana properties of Chakramarda Beeja helps in alleviating Kandu, pidika symptoms of the disease. Thrachrysone isolated from seeds showed stronger anti-oxidant activity(19).

Trikatu helps as shula hara(ruja). Blood purifying and, wound healing properties of Vidanga shows kusthaghna action on skin(20). Wound healing activity of embelin isolated from the ethanol, extract of leaves of embelica ribesburm(21).

Varnya property of kusta drug reduces discolouration(vivarnata) of the skin. . Melanogenesis inhibitory compounds from saussureae Radix(22)

Mahucchista having vrana ropana property acts as kusthaghna.

Narikela taila improves skin hydration, lauric acid present in narikela taila possess bactericidal, fungicidal and anti-inflammatory properties.

Recent research work shows that these drugs are having potent Anti-allergic, Anti-inflammatory, Immunomodulatory, chemo protective, Anti-bacterial, Anti-oxidant, Anti- ulcerogenic, Anti-microbial and Anti-fungal properties.

\section{Pruthu Nimba Panchaka churna}

Nimba having tikta, kashaya rasa, laghu guna, sheeta veerya, katu vipaka shows pitta shamaka kaphaghna, vrana ropana, krimighna, kandughna, daha prashamana, rasayana properties.

Neem bark and leaf shows Anti-inflammatory, Anti-bacterial and Anti-fungal properties. Neem seed shows anti leprotic, Anti-helmenthic properties.

Neem flowers are used in vitiated conditions of pitta and kapha.it has anti helmenthic property.

Neem gum is reported to be useful in treatment of skin diseases. Nimba has Vrana shodhaka property.

A plant derived wound therapeutic for costeffective treatment of post-surgical scalp wounds with exposed bone(23)

Sroto shodaka property of Maricha and Haritaki helps in proper circulation and nourishes the tissues.
Pippali acts as kaphaghna due to its Deepana, Pachana and Ama dosha hara property. Anulomana guna of hareetaki, Sunti and Vibheetaki alleviates Pitta dosha, one of the vitiated doshas in vicharchika. Maricha acts as shula hara, Amalaki act as Rakta shodaka as well as Daha prashamana.

Triphala having rechaka property alleviates pitta dosha.

Go ghrita having madhura rasa guru guna sheeta veerya katu vipaka alleviates vata and pitta doshas and shows kusthaghna property.

Madhu having madhura kashaya rasa guru guna, sheeta veerya, katu vipaka alleviates Tridoshas and shows lekhana, shodana, Anti-inflammatory, Antioxidant and Anti-fungal properties.

These drugs are also having Raktashodhaka and Raktaprasadana properties, because of Tikta and Kashaya rasa dominance, Rakta is one of the main dushya in tvak vikara. These properties have direct positive effect on Tvak dhatu.

\section{Conclusion}

The experiment clearly concludes that Mulaka beejadi lepa and pruthu nimba panchaka churna for external application could be a remedy for Vicharchika and can be used in other Kustha also especially Kaphaja-pittaja kushthas explained in the classic texts without any side effects. It will be a panacea for many of the skin problems. Thus the clinical study clearly concludes that this should be a best remedy.

\section{Reference}

1. Parthasaradhy, IAP text book of Paediatrica $5^{\text {th }}$ edition, chapter no -18.6, pg.no989, JP Publications 2013.

2. Agnivesa, caraka samhita edited with Vidyotini Tika by Kasinath sastry and Gorakanath caturvedi, Vol-III, Cikitsa Sthana verse no -13, pg.no - 324.

3. Agnivesa, caraka samhita edited with Vidyotini Tika by Kasinath sastry and Gorakanath caturvedi, Vol-II, Nidana Sthana, pg.no - 68 .

4. Sharma R.K. Bhagavan Dash, Charaka Samhita, of Agnivesa, revised y Charaka and Dridhabala, Chaukambha Bharati Academy, Varanasi 2010, vol-3, Chikitsa Sthana-7, Verse no. 26.

5. Acharya Susruta, Susruta Samhita, vol -1, Edited and published by prof. G.D. Singhal, Chaukambha Sanskrit Pratisthan, Delhi, Reprint 2007, Nidana sthana-5, Verse no. 13.

6. Vruddha jeevaka,kasyapa Samhita,edited by P.v.Tewari , Chaukambha Bharati Academy, Varanasi 2016, chikitsa sthana-9, kustha chikitsataadhyaya, verse no:2,page no:197.

7. Agnivesa, caraka samhita edited with Vidyotini Tika by Kasinath sastry and Gorakanath caturvedi, Vol-I, Sutra Sthana verse no -16, pg.no - 405.

8. Nicholas A. Boon nicki R. colledge brian R. Walker, Davidson's principles and practice of medicine, $20^{\text {th }}$ edition pg.no- 1284.

9. OP Ghai, Ghai Essential Pediatrics, $7^{\text {th }}$ edition, chapter no-24, Page no-669, CBS Publishers, New Delhi, 2009.

10. Robert M. Klingman \& others, Nelson textbook of 
Pediatrics, 19th Edi., vol.-1, Chapter No.- 139, Page No.- 801, Saunders, An imprint of Elsevier, 2013.

11. Parthasarthy, IAP textbook of Pediatrics, 5th Edi., Chapter No.-18.6, Page No.- 999,1000, JAYPEE Publication, 2013.

12. Sri Jagadish Vara Prasad tripati, edited by Bhisagratna PT. Bramha shankara Mishra, Cakradatta of sri cakrapanidatta, Krishnadas Academy, edition-1983, pg.no - 393-394.

13. Ramanivasa Sharma, Sahasrayogam, edition-oct1989, pg.no- 113

14. Robert M. Klingman \& others, Nelson textbook of Pediatrics, 19th Edi., vol.-1, Chapter No.- 139, Page No.- 801, Saunders, An imprint of Elsevier, 2013.

15. Khare $\mathrm{C} \mathrm{P}$, Springer, Indian medicinal plants, reprint - 2008 pg.no-531

16. Jadoun. J, Yazbak A, Rushrush S, Rudy A, Azaizeh H. PMID:27781070 \{pubmed\}
17. Khare $\mathrm{C} \mathrm{P}$, Springer, Indian medicinal plants, reprint - 2008 pg.no-99-100.

18. Khare C P, Springer, Indian medicinal plants, reprint - 2008 pg.no-524.

19. Khare C P, Springer, Indian medicinal plants, reprint - 2008 pg.no-130.

20. Khare C P, Springer, Indian medicinal plants, reprint - 2008 pg.no-237.

21. Kumara swamy HM, Krishna V, shankarmurthy K, abdul rehaman $\mathrm{B}$, mankani $\mathrm{KL}$, Mahadevan KM, hareesh $\mathrm{BG}$, rajanayaka $\mathrm{H}$, PMID:17034970.

22. Choi JY, choi EH, jung HW, oh JS, lee WH, lee JG, son JK, kim Y, lee S PMID: 18409040.

23. Lauchli S, vannotti S, hafner J, hunziker T, French L PMID: 24851844. 